\title{
Methoxsalen with UItraviolet A Therapy
}

National Cancer Institute

\section{Source}

National Cancer Institute. Methoxsalen with Ultraviolet A Therapy. NCI Thesaurus. Code C44398.

Strong evidences have indicated causal association between 8-methoxypsoralen with UVA (PUVA) treatment and non-melanocytic skin patients with psoriasis. 8-

Methoxypsoralen alone did not alter the incidence of new skin cancer development in a 2year study. In a large number of studies, 8-Methoxypsoralen in combination with ultraviolet A radiation induced chromosomal aberrations, sister chromatid exchanges, mutation, DNA damage and DNA cross-links in human cells in vitro. This treatment is classified as carcinogenic to Human by IARC. (NCI05) 